\title{
Examination of the Effect of Positive Psychology- based Group Counseling on Lying Tendencies"
}

\author{
Muhammet Aykuthan Ulusoy ${ }^{1}$ \\ Osman Sezgin $^{2}$ \\ Ministry of Education \\ Marmara University
}

\begin{abstract}
"This study was generated from the doctoral dissertation entitled "The Effectiveness of Positive Psychology-based Group Counseling on Lie-telling Tendency and Self-respect of 7th Grade Students" prepared by the first author (2020) under the supervision of the second author; it was supported by Marmara University Department of Scientific Research Projects Coordination. Project Number: EGT-C-DRP-200318-0145

${ }^{1}$ Dr., Ministry of Education, Gaziantep, Turkey. E-mail: muhammetaykuthan@gmail.com

${ }^{2}$ Asst. Prof. Dr., Marmara University, Department of Educational Sciences, Guidance and Psychological Counseling, Istanbul, Turkey. E-mail: osezgin@marmara.edu.tr
\end{abstract}

\author{
Corresponding author: \\ Muhammet Aykuthan \\ Ulusoy \\ E-mail: \\ muhammetaykuthan@ \\ gmail.com
}

eISSN: 2458-9675

Received: 05.11.2020

Revision: 04.02.2021

Accepted: 07.02.2021

(C)Copyright 2021

by Author(s)

\begin{abstract}
This study was carried out to apply positive psychology-based group counseling activities, which were prepared to reduce the tendency of 7th grade students to lie and created considering Turkish-Islamic cultural values, and to test the effectiveness of the activities. In the quantitative part of the study in which the mixed method design was preferred, a quasi-experimental design consisting of experimental, control, and placebo groups was used. The quantitative phase of the study was carried out with 68 students, 22 of whom were in the experimental group, 24 in the control group, and 22 in the placebo group, studying in a secondary school in Gaziantep where permission for the study was obtained. The study group for the quantitative stage of the study was determined by the analogous cluster sampling method. The lying tendency scale and the assertiveness inventory were used as data collection tools for this stage. The study group at the qualitative stage, which was completed by performing a case study, was determined using the criterion sampling method and was carried out with the teachers and parents of the experimental group. In the qualitative part of the study, a structured interview form was used as a data collection tool. The study found a significant difference in the lying of the experimental group, no significant difference in the lying tendency of the control and placebo group, significant differences between the difference scores of the groups' lying tendencies, and a significant difference in the assertiveness scores of the placebo group. Keywords:

Lying, positive psychology, group counseling activities
\end{abstract}

Pozitif Psikoloji Temelli Grup Rehberliğinin Yalan Söyleme Eğilimlerine Etkisinin İncelenmesi

Öz

Bu çalışma 7. sınıf öğrencilerinin yalan söyleme eğilimlerini azaltmaya yönelik olarak hazırlanan, Türk İslam kültuir değerlerine duyarlı bir şekilde oluşturulan pozitif psikoloji temelli grup rehberlik etkinliklerini uygulamak ve uygulanan etkinliklerin etkililiğini smamak amacıyla gerçekleștirilmiștir. Karma yöntem deseninin tercih edildiği çalışmanın nicel kısmında deney, kontrol ve plasebo gruplarından oluşan yarı deneysel desen kullanılmıştır. Çalışmanın nicel aşaması, Gaziantep ilinde uygulama izni alınan bir ortaokulda öğrenim gören 22'si deney, 24’ü kontrol ve 22'si plasebo olmak üzere 68 öğrenci üzerinde yürütülmüştür. Nicel aşamaya ait çalışma grubu, benzeşik küme örnekleme yöntemi ile belirlenmiştir. Nicel kısımda veri toplama aracı olarak, yalan söyleme eğilimleri ölçeği ile atılganlık envanteri kullanılııştır. Durum çalışması gerçekleştirilerek tamamlanan nitel aşamadaki çalışma grubu, ölçuit örnekleme yöntemi ile belirlenmiş ve deney grubunun öğretmenleri ile velileri üzerinde yürütülmüsstür. Nitel kısımda veri toplama aracı olarak yapılandırılmış görïşsme formu kullanılmıştır. Araştırma bulgularında deney grubunun yalan söyleme eğilimlerinde anlamlı bir farklılık olduğu, kontrol ve plasebo gruplarının yalan söyleme eğilimlerinde anlamlı bir farklılık olmadığı, grupların yalan söyleme eğilimlerine ait fark puanları arasında anlamlı farklılıklar olduğu ve plasebo grubunun atılganlık puanlarında anlamlı bir farklılık olduğu sonucuna ulaşılmıştır. Anahtar Kelimeler:

Yalan söyleme, pozitif psikoloji, grup rehberlik etkinliği 
Based on the availability of information and acceptance of individual differences, there is not one generic solution for personal problems, but unique individual solutions. The unique strengths of a person arise from their character. A new method used by positive psychology argues that there should be preventive services beyond treatment-centered, and emphasizes that character strengths should be used before or after the encountered problem. Although it has not been completely named, the concept of "human transcendental experiences" expressed by James in the early 1900s and the views that these experiences can stimulate the most appropriate functioning of the human organism (Rathunde, 2001 as cited by Linley \& Joseph, 2004) can be referred to as positive psychology. In addition, Maslow's ideas suggesting a new method emphasizing an eclectic approach exhibiting a structure that will expand the scope of existing trends in psychology (Maslow, 1954) demonstrate the historical background of positive psychology. Conceptualization of the issue coincides with the early 2000s. Seligman and Czikszentmihalyi, who thought the structure of psychology that places pathology at its center should be re-evaluated, have suggested that studies on strengthening the current situation could be a technique to eliminate existing problems. On the other hand, it is stated that the things that make life worth living will increase by focusing on the strong character traits of the individual, and thus there should be studies showing that the problem can be prevented (Aspinwall $\&$ Staudinger, 2003). Positive psychology believes that humans have a natural potential (Bugental, 1964, as cited by Linley \& Joseph, 2004) and aims to discover human virtues with their strengths and character, thus creating an alternative to psychological approaches that focus on the weaknesses of humans (Marujo \& Neto, 2014). In fact, the question is: "How can I be happy?" instead of "What can I do now, am I depressed?" (Driver, 2011). Treatment is defined as not just fixing what is broken; it is nurturing what is best (Seligman \& Csikszentmihalyi, 2000). In this regard, the aim of positive psychology is repairing the worst things in life and building positive qualities (Seligman \& Csikszentmihalyi, 2000).

Human beings have sought ways to be happy since the day they were created. Positive psychology uses the concepts of self-realization, satisfaction, harmony, quality of life, and well-being in this pursuit of happiness. In other words, achieving happiness is possible with a focus on these concepts in life. The concept of happiness is the excess of positive thoughts and feelings about the life of the individual; it is also the sum of the experiences and positive emotions from life (Kangal, 2013). Happiness of individuals and their psychological state are positively related and positive psychology-based interventions contribute positively to this happiness (Sin \& Lyubomirsky, as cited by Parks \& Schueller, 2014). Diener and Fredrickson reported that a happy person is someone who tends to be happier or more positive (Solano, 2014). The concept of self-realization includes selfhonesty, self-confidence, being authentic and natural, and contemplation of the work done (Maslow, 2001). When viewed within the context of positive psychology, it includes an individual's moments of awe, showing kindness, and enjoying the work done (Peterson \& Seligman, 2004). Honesty, self-confidence, authenticity, naturality, showing kindness, 
and awe for the work done prove the wisdom of the person. Wisdom is related to the experiences of life and to making an effort, self-improvement, and self-realization (Ardelt, 1997 as cited by Scheibe, Kunzmann, \& Baltes, 2009 as cited by Compton \& Hoffman, 2013). When satisfaction is viewed from the perspective of psychology, the concepts of life satisfaction and enjoying life come to mind, both of which mean that the individual is satisfied with his/her conditions of life and has the joy of living (Akın \& Yalnız, 2015). Subjective well-being is the ability of the individual to evaluate the experiences of life positively and to display positive feelings about negative experiences (Diener at al., 1999 as cited by Ruini, 2017). Studies have found that satisfaction directly contributes to wellbeing (Cheetham, Williams, \& Bednall, 2016). Kabakçı (2013) stated that enjoying life (satisfaction) significantly predicts subjective well-being. Man is a bio-social being and must meet his physiological, psychological, and social needs in order to survive. Meeting needs is related to an individual's adaptation level (Avşaroğlu \& Üre, 2007) and positive or negative emotions experienced during this adaptation process affect happiness. Quality of life, another factor affecting happiness, is an indicator of an individual's satisfaction from life. It emerges depending on the individual's evaluation of their life as happy, high quality, and ideal, and is built on emotional foundations. Positive feelings about life increase life satisfaction (Korkmaz, Germir, Yücel, \& Gürkan, 2015). Studies have found that quality of life plays a role in happiness. Akyüz, Yaşartürk, Aydın, Zorba, \& Türkmen (2017) report that as quality of life increases, the level of happiness increases, and Korkmaz, Germir, Yücel, \& Gürkan (2015) note that there is a causal relationship between personal and family happiness, and the factors of happiness, satisfaction, and hope. The concept of flow, which has an important place in the theory of positive psychology, expresses the situations where time passes rapidly and a person's attention is completely directed to an activity (Lopez, 2008). Flow, the moment when the person is not involved in anything else and the spontaneous feeling of focusing on the situation (Barker \& Galajda, 2016), is composed of interpersonal relationships and quality of life, the ability to break out of life's patterns, and having a unique personality (Csikszentmihalyi, 1997). To establish flow completely and make the experience enjoyable, finding clear goals, having instant feedback on one's actions, a balance between difficulties and skills, the need to combine action and awareness, concentration, lack of concern for failure, loss of self-consciousness within the framework of the work done, disappearance of the feeling of time, and the events be authentic is required (Csikszentmihaly, 2007). Flow is, first of all, a subjective state in which even the activity itself is totally forgotten. Its peculiarity is intense experiential participation in an instant activity. Attention is fully invested in the task at hand and the person works at full capacity (Csikszentmihalyi, 2014). The concept of flow is defined as concentrating one's attention by focusing on the job they do and it is supported in counseling by focusing on character strengths. Studies conducted by Peterson and Seligman have noted that focusing on strengths makes it easier to overcome existing problems. Within this framework, The Via Classification of Strengths (VIA), which consists of six virtues and twenty-four character strengths, has been developed. 
The VIA ensures that the strengths of the individual are systematically absorbed in the character (Lopez, 2009). Thus, the positive aspects are supported and the effect of weaknesses that the person sees as a problem in their life is reduced.

Table 1.

VIA (The Via Classification of Strengths) (Peterson \& Seligman, 2004)

1. Wisdom: Cognitive strength that entails the acquisition and use of knowledge.

1.1. Creativity (originality, ingenuity): Thinking of novel and productive ways to conceptualize and do things. It includes artistic achievement but is not limited to it.

1.2. Curiosity (interest, novelty-seeking, openness to experiences): Taking an interest in ongoing experiences. It refers to exploring fascinating topics.

1.3. Judgment (open-mindedness; critical thinking): Thinking things through and examining them from all sides; being able to change one's mind in light of evidence; weighing all evidence fairly.

1.4. Love of Learning: This refers to strength of character and curiosity about mastering new skills; tendency to add systematically to what one knows.

1.5. Perspective (wisdom): Being able to provide wise counsel to others; having

1.6. ways of looking at the world that make sense to oneself/others

2. Courage: Emotional strength to accomplish goals. It involves one's exercise of will.

2.1. Bravery (valor): Strength of character that means speaking up for what's right even if situations encountered include threats, difficulty, pain, or challenges. It

includes physical bravery but is not limited to it.

2.2. Perseverance (persistence, industriousness): Being able to finish what one starts and to persevere in a course of action despite obstacles.

2.3. Honesty (authenticity, integrity): Speaking the truth but more broadly presenting oneself genuinely and acting in a sincere way. Being without pretense, seeming the way one is. It refers to taking responsibility for one's feelings and actions.

2.4. Zest (vitality, enthusiasm, vigor, energy): Approaching life with excitement and energy; not doing things halfway or halfheartedly; feeling alive.

3. Humanity: Interpersonal strength that involves tending to and befriending others.

3.1. Love: Valuing close relations with others, in particular, those in which sharing and caring are reciprocated. Being close to people.

3.2. Kindness (generosity, care, compassion, altruism): Strength of character that includes doing favors and good deeds for others, helping them, and taking care of them.

3.3. Social Intelligence (emotional intelligence, personal intelligence):Being aware of the motives/feelings of others and oneself. Knowing what to do to fit into different social situations.

4. Justice: Civic strength that underlies healthy community life.

4.1. Teamwork (citizenship, social responsibility, loyalty): Strength of character that requires working well as a member of a group or team, being loyal to the group, and doing one's share.

4.2. Fairness: Treating all people the same according to notions of fairness and justice. Not letting feelings bias decisions about others.

4.3. Leadership: Encouraging a group of which one is a member to accomplish goals.

5. Temperance: Strength that protects against excess.

5.1. Forgiveness: Being able to forgive the mistakes made by accepting the shortcomings of others in interpersonal relationships. It requires not being vengeful.

5.2. Modesty: Not regarding oneself as more special than one is.

5.3. Prudence: Being able to be careful about one's choices. Not saying or doing things that might later be regretted.

5.4. Self-Regulation (self-control):Regulating what one feels and does. It requires being disciplined and controlling one's emotions

6. Transcendence: Strength that forges connections to the universe and provides meaning.

6.1. Appreciation of Beauty and Excellence: Noticing and appreciating beauty, excellence, and/or skilled performance in various domains of life.

6.2. Gratitude: Being aware of and thankful for the good things that happen.

6.3. Hope (optimism, future-mindedness, future orientation): Expecting the best in the future and working to achieve it and believing that a good future is something that can be brought about.

6.4. Humor Being able to do something that makes other people laugh.

6.5. Spirituality (religiousness, faith, purpose): Having coherent beliefs about the meaning of life that shape conduct and provide comfort. 
In positive psychology, character strengths are used to strengthen weaknesses by supporting the forces present in the character of the person, in contrast to the approach of defining personality problems and discomfort symptoms (Chu \& Chao, 2015). A study conducted with high school students reported that character strengths significantly predict a person's well-being, resilience levels, and academic achievement (Kabakç1, 2013), while another study carried out with participants with more severe problems found that supporting character strengths leads to noticeable improvement related to positive relationships and self-acceptance (Meyer, Johnson, Parks, Iwanski, \& Penn, 2012). It is a reality that human beings have been in contact with other people since the day they existed. It can be argued that the strengths and weaknesses of the person's perspective on life affect this communication. If evaluated in this context, the concept of honesty can emerge as an indispensable necessity of communication. Achieving honesty seems possible by not lying.

The word lie - "yalan" in Turkish etymologically evolved from "yalgan" to "yalkan" to "yalan" (Erdal, 2016) - is a verb meaning to hide the truth, to distort the truth, or to claim that something exists that does not. A person who displays this behavior or adopts it as a habit is called a liar (Soysald1, 2005). The purpose of this behavior, displayed with the aim of providing material or spiritual benefit, is to purposefully and willingly deceiving the other person (Girişken, 1974). It is a situation that depends on verbal or non-verbal statements (Isenberg, 1964, as cited by Druzin \& Li, 2017). The relevant literature classifies lying behavior into three categories: lies of deception, pathological lies, and white lies; lies of deception are divided into eight different categories. Although the types of lies described as pathological lies and white lies also include the act of deception, these two types of lies differ from lies of deception in terms of the purpose of lying and the presence of mental distress. A situation where a person does not tell what they know to another person is considered a lie of silence since there is the quality of deceiving the other person by staying silent (Ekman, 1992). Lies told to overcome undesirable situations by bragging and inventing excuses are viewed as lies of defense (Goleman, 1999). Imaginary lies that emerge in cases where right and wrong cannot be distinguished in time and space are common behaviors seen especially during childhood. Social lies told as a result of not being able to control and socialize one's own behavior (Koç, 2007) can be described as lies that are conveyed from person to person when people who are models show false behaviors. An individual can learn that they can lie and overcome difficult situations they encounter in social situations. Later, they do not see any problem in applying this solution in their life (Uzun, 2011). Lies told for the purpose of being liked (Uzun, 2011) based on a desire of being included in a group or admired are described as extolled lies. Gossip lies, nurtured from feelings such as hostility and jealousy (Karpman, 1949), are defined as talking about a person in order to cause harm. Pathological lies, which differ in terms of deceiving the individual themselves as well as others, damage both the other person and the development and personality of the person telling the lie (Ford, 1997). Pathological lies are the expressions of those who 
place lies at the center of their life, whose reason is based on neurological disorders, or who see lying as a reason for pleasure (Samsakç1, 2015). Examples of pathological lies include narcissistic personalities' being more prone to lying (Ford, 1997) and showing symptoms close to pathological lying (Tura, 2005), the presence of continuous lying among the diagnostic criteria of antisocial personality disorder (DSM IV-R), hysterics' telling lies unnecessarily to draw the attention of others (Köroğlu \& Bayraktar, 2010), paranoids' resorting to lying behavior by ignoring all contrary evidence because they think that they are constantly being manipulated (Butcher, Mineka, \& Hooley, 2013), and making up false information based on confabulation emerging unintentionally (Gündoğar \&e Demirci, 2007). There are studies reporting that lying is simply regarded as an unwanted behavior (Özer, Bozkurt \& Tuncay, 2005; Ünal, 2006; Şehirli, 2007; Yaman, Mermer, \& Mutlugil, 2009), as well as being a behavioral problem (Kanlıkılıçer, 2005; Şehirli, 2007). Within the context of positive psychology, character strengths of the individual - self-acceptance, justice, courage, forgiveness, gratitude, and patience — can reduce lying behavior.

\section{Method}

\section{Research Design}

In the study, the mixed method was preferred as a research model to examine the structures more deeply (Edmonds \& Kennedy, 2017), to focus on the feelings and thoughts of the participants, and to provide ease of generalization about a large group (Creswell \& Clark, 2014). Qualitative data were collected to determine the effectiveness of positive psychology-based group counseling, which was prepared within this framework. This method, described as explanatory sequential design, aims to follow quantitative results with qualitative data (Edmonds \& Kennedy, 2017) to explain the quantitative results in more detail (Edmonds \& Kennedy, 2017).

In the first part of the study, quantitative research methods included a quasiexperimental pre-test/post-test design with experimental, control, and placebo groups. In the second part, specific results were sought to support the quantitative data obtained and a qualitative follow-up study was performed. In this context, qualitative data were collected after the experimental process to determine whether the applied program was effective. Experimental designs aim to determine causeand-effect relationships between variables (Büyüköztürk, 2011). The design of the experiment can be defined as a $3 \times 2$ mixed pattern. In the design, the first factor showed implementation groups (experimental, control, and placebo) and the second factor showed the repeated measures (pre-test, post-test). The dependent variable of the design was students' tendency to lie; the independent variable was group counseling activities based on positive psychology, which is the experimental process whose effect was tested. Before the procedures, the lying tendency scale was 
administered to the experimental and control groups and the lying tendency scale and the assertiveness inventory were administered to the placebo group. After the pre-test, students in the experimental group were engaged in positive psychologybased group counseling activities (15 sessions) prepared by the researcher and the placebo group undertook an assertiveness training program (10 sessions) prepared by (Ugürol, 2010). The control group did not participate in any activity during this period. After the procedure was applied to the experimental and placebo groups, the lying tendency scale was administered to the experimental and control groups as the post-test; the students in the placebo group took the lying tendency scale and the assertiveness inventory. In the second part of the study, a case study, a qualitative research method, was used to evaluate the subject matter or events from a holistic perspective (Yıldırım \& Şimşek, 1999). In this framework, opinions of the teachers and parents of the students in the experimental group about the applied program were obtained using interviews and the effect of the program was evaluated.

\section{Study Groups}

The study group for the quantitative stage of the study was determined by the analogous cluster sampling method. The study group included 7th grade students of a secondary school in Gaziantep, where permission to conduct the study was obtained, forming the analogous subgroups needed for the sampling method (Büyüköztürk, Çakmak, Akgün, Karadeniz, \& Demirel, 2014). The group matching method was preferred as it was not possible to impartially assign the groups. Since the students in the groups were in the same grade, the groups were equal in age; they were also equal in socio-economics as they were from the same neighborhoods in the enrollment area. To create group matching, one class was determined as the experimental group (class 2), one class the control group (class 4), and one class the placebo group (class 6) between the branches in 7 th grade by drawing lots and using the random sampling method.

The study groups in the quantitative part of the study were determined using the criterion sampling method. This sampling technique aims to review and examine all cases that meet some predetermined criteria (Patton, 2015). In this context, it is possible to examine all cases that meet a predetermined set of criteria (Y1ldırm \& Şimşek, 1999). Teachers who taught the lessons to the experimental group for at least one semester for more than two hours per week were included in the study. Parents who actively participated in the social post-sharing group created during the study process and agreed to participate in the study were included in the study.

\section{Data Collection Tools}

The "Lying Tendency Scale" and "Assertiveness Inventory" were used as data collection tools in the study. 


\section{Lying Tendency Scale}

The lying tendency scale was developed by Ulusoy (2020) and it consists of two dimensions: lying for social reasons and lying for emotional reasons. The scale comprises 23 statements to which responses are given according to a five-point Likerttype scale. Participants' responses to the items of the scale are given as "never=1", "seldom=2", "sometimes=3", "usually=4", and "always=5". No item is reverse-scored in the scale; the minimum score is 23 and the maximum score is 115 . High scores indicate that the student's tendency to lie increases. Similar scoring methods are applied to the subdimensions. The content validity ratio (CVR) of the scale was .51, the content validity index (CVI) was .76, and the Kaiser-Meyer-Olkin (KMO) value was .91. According to the exploratory factor analysis (EFA) results, the explained variance of the scale was $42.8(n=391)$. According to the confirmatory factor analysis results (CFA), the two-factor structure of the scale was verified in a sample of middle school students. In this context, the fit indices were $\mathrm{x}^{2} / \mathrm{sd}=2.44$; $\mathrm{RMSEA}=.056$; $\mathrm{SRMR}=.045$; $\mathrm{TLI}=.903$; and $\mathrm{CFI}=.914$. To determine the criterion validity of the scale, the social phobia scale was used for children and adolescents and statistically significant positive correlations were found between the scales $(r=.309, p<.05)$. The reliability of the scale was determined using the Cronbach's alpha coefficient. The internal consistency coefficients were calculated as $\alpha=.913$ for the entire scale, $\alpha=.887$ for the lying for social reasons, and $\alpha=.844$ for the lying for emotional reasons subscales. As a result of the test-retest reliability, statistically significant relationships were found between all the subscales and total scale scores. The lowest relationship was in the lying for emotional reasons subscale $(\mathrm{r}=.561 ; \mathrm{p}<.001)$ and the highest was in the lying for social reasons subscale $(\mathrm{r}=.796 ; \mathrm{p}<.001)$. The relationship between the total scores obtained from the scale in terms of the 1st and 2nd practice was significant $(r=.768 ; \mathrm{p}<.001)$.

\section{Assertiveness Inventory}

The assertiveness inventory consists of 45 items. There are nine reverse-scored items $(4,9,13,18,22,27,31,36$, and 40$)$ in the scale and responses are given as no=1 and yes $=0$. The minimum and maximum scores on the scale are 14 and 45 , respectively. As the score approaches 45 , assertiveness increases. The relationship between the scores of 100 participants who had timid and assertive characteristics during the scale development phase was .74. Based on this, item analysis was carried out. The reliability coefficient was .72 and the stability coefficient was .80 (Erdoğan \& Uçukoğlu, 2011).

\section{Teacher and Parent Interview Forms}

Teacher and parent interview forms were prepared on the basis of the aims of the positive psychology-based group counseling activities program and the relevant literature. A draft of the form was checked by an expert in the field and a linguist, the 
questions were carefully prepared to be clear and understandable, and it was designed to allow the participants to express their experiences in detail. Specific questions were prepared, a directive manner was avoided, and one-dimensional questions were asked. Probes were used so that experiences could be expressed in detail.

\section{Data Analysis}

Parametric tests were used for the data that met the assumption of normality obtained from the pre-test and post-test applied to the experimental, control, and placebo groups; nonparametric tests were used for the data that did not meet the assumption of normality. Paired groups t-test, Wilcoxon signed-rank test, one-way variance analysis, and descriptive analysis method were applied to the qualitative data.

\section{Process}

Positive psychology-based group counseling activities included 15 sessions. Gains of the sessions were as follows:

Session 1: Expresses positive emotions

Process: The aim of the study was explained, group rules were set, and the pre-test was administered. Messages about emotions, and basic and subordinate emotions were obtained and participants were informed about the topic. Awareness about positive emotions and characteristics was increased and the participants were enabled to discover positive emotions and characteristics that they usually use.

Session 2: Allows individuals to directly express themselves in the group

Develop self-acceptance behavior among others

Realize the importance of self-acceptance in the peer group

Process: Awareness about the factors that trigger positive emotions for positive personal characteristics was raised. Messages were received using the activity applied, thus enabling the participants to express themselves directly within the group. Messages regarding the effect of self-acceptance on personal integrity were obtained and display of self-acceptance in others and peer groups was ensured.

Session 3: Realizes that the individual has to believe that they can achieve.

Express the importance of self-acquaintance and the need to act accordingly.

Process: The fact that the participants become aware of their strong character traits and the importance of self-acquaintance was emphasized, and it was ensured that success was related to acting in accordance with their own characteristics. 
Session 4: Realizes the importance of positive friends.

Process: Messages about the type of communication the participants had during happy moments they spent with their friends and what kind of feeling this state caused were received. Thus, the effect of positive friends was highlighted.

Session 5: Realizes the importance of justice and righteousness

Process: In the activity, aiming to teach concepts of justice and righteousness, messages including reflections of these virtues practiced in daily life were shared.

Session 6: Explains the relationship between righteousness and characteristics

Process: Messages about the effect of the concept of righteousness on daily behaviors were received and awareness about the contribution of righteousness to interpersonal communication was increased.

Session 7: Learns the characteristics of the concept of courage

Process: Participants were informed about the definition and features of the concept of courage. Messages on the subject were received. The effect of courage on accepting one's behavior, taking responsibility, and thinking it over were emphasized.

Session 8: Knows the characteristics of a person who displays courage

Exemplifies characteristics including courage

Process: Participants were enabled to notice persons displaying the courage characteristic and exemplify this characteristic in their lives.

Session 9: Supports the concept of courage with examples they have illustrated Realizes the positive effect of the courage characteristic

Process: Participants' awareness about the necessity of courage in social life and its contribution to righteousness was increased by enabling the participants to present products about the concept of courage.

Session 10: Knows the concept of forgiveness

Explains the concept of forgiveness using examples from their lives.

Explains the concept of forgiveness of others with examples from their lives.

Process: Participants were enabled to learn the concept of forgiveness. Participants' awareness about forgiveness was increased by enabling them to give examples of forgiveness characteristics and forgiving others from their life. 
Session 11: Has knowledge about examples of forgiveness

Learns that forgiving is a love-based characteristic.

Understands the importance of forgiving.

Process: Participants were enabled to explain the concept of forgiveness using examples from their life and notice the relationship between forgiveness and love.

Session 12: Notices positive emotions of forgiveness provided to human beings.

Process: Awareness about forgiveness was increased by receiving messages including positive emotions felt when forgiveness was shown.

Sessions 13 and 14: Notices the effect of the feeling of gratitude on personal well-being.

Develops the gratitude characteristic and learn to behave accordingly

Process: Awareness about positive emotions arising as a result of the gratitude characteristic was ensured.

Session 15: Notices the relationship between patience and success.

Realizes the relationship between patience and anger management.

Process: Messages including the importance of setting a goal and the role of patience in attaining a goal were received. Messages about the relationship between patience and anger management were received and the importance of patience was discussed.

\section{Results}

\section{Quantitative Results}

This section includes results obtained as a result of evaluation of the hypotheses.

Hypothesis 1: "There is a significant difference between the pre-test and post-test scores of the experimental group who undertook positive psychology-based group counseling activities." The paired groups t-test was used to test the first hypothesis of the study, and the results are presented in Table 2.

Table 2 shows that there is a significant difference between the pre-test and post-test scores of the experimental group on the lying tendency scale $(p<.025)$. The significant difference was determined in both total scale score and scores of the subscales. Effect size, which was developed by Cohen (1988), is regarded as large at the level of $>0.8$. Accordingly, the analysis showed a large effect size (total test score $=1.34$, lying for 
Table 2 .

Pre- and Post-test Scores of the Experimental Group

\begin{tabular}{|c|c|c|c|c|c|c|c|c|}
\hline \multicolumn{2}{|c|}{ Lying Tendency Scale } & $\mathbf{n}$ & $\overline{\mathbf{x}}$ & sd & $\mathrm{t}$ & df & $\mathrm{p}$ & Cohen's d \\
\hline \multirow{2}{*}{ Scale Total } & $\begin{array}{l}\text { Experimental } \\
\text { Pre-test }\end{array}$ & 27 & 45.41 & 11.48 & \multirow{2}{*}{4.16} & \multirow{2}{*}{21} & \multirow{2}{*}{.000} & \multirow{2}{*}{1.34} \\
\hline & $\begin{array}{l}\text { Experimental } \\
\text { Post-test }\end{array}$ & 22 & 32.60 & 7.48 & & & & \\
\hline \multirow{4}{*}{ Subscales } & $\begin{array}{l}\text { Lying for social reasons } \\
\text { Pre-test }\end{array}$ & \multirow[b]{2}{*}{22} & 27.14 & 9.59 & \multirow[b]{2}{*}{3.89} & \multirow[b]{2}{*}{21} & \multirow[b]{2}{*}{.001} & \multirow[b]{2}{*}{1.21} \\
\hline & $\begin{array}{l}\text { Lying for social reasons } \\
\text { Post-test }\end{array}$ & & 18.14 & 4.29 & & & & \\
\hline & $\begin{array}{l}\text { Lying for emotional reasons } \\
\text { Pre-test }\end{array}$ & \multirow{2}{*}{22} & 18.27 & 4.04 & \multirow{2}{*}{3.56} & \multirow{2}{*}{21} & \multirow{2}{*}{.002} & \multirow{2}{*}{0.95} \\
\hline & $\begin{array}{l}\text { Lying for emotional reasons } \\
\text { Post-test }\end{array}$ & & 14.46 & 3.94 & & & & \\
\hline
\end{tabular}

social reasons subscale $=1.21$, lying for emotional reasons subscale $=.95$ ). When the analysis was examined in terms of mean scores, the scores of the experimental group decreased in the procedure after the process.

Hypothesis 2: "There is a significant difference between the mean pre-test and post-test scores of all the groups in favor of the experimental group." One-way analysis of variance was used to test the second hypothesis of the study, and the results are shown in Table 3 and Table 4.

Table 3.

Scores of the Experimental, Control, and Placebo Groups

\begin{tabular}{lcccccc}
\hline Source of variation & Sum of Squares & Sd & Mean of Squares & F & p & $\eta^{2}$ \\
\hline Intergroup & 2373.462 & 2 & 14.44 & & & \\
\cline { 1 - 5 } Intragroup & 17257.170 & 65 & 20.19 & 4.47 & .015 & 0.12 \\
\cline { 1 - 5 } Total & 19630.632 & 67 & 12.91 & & & \\
\hline
\end{tabular}

Table 4.

The Mean and Standard Deviation Scores of the Experimental, Control, and Placebo Groups

\begin{tabular}{lccc}
\hline Groups & $\mathbf{n}$ & $\overline{\mathbf{x}}$ & $\mathbf{s d}$ \\
\hline Experimental & 22 & 12.82 & 14.44 \\
Control & 24 & -.88 & 20.19 \\
Placebo & 22 & 1.82 & 12.91 \\
\hline
\end{tabular}

Table 3 and Table 4 show that there is a significant difference between the mean scores of the experimental, control, and placebo groups $(p<.025)$. When the effect value of the significant difference was examined, it had a moderate effect (0.12). Post hoc analysis was performed to determine the group that caused this significance and the results are shown in Table 5. 
Table 5.

Post Hoc Analysis of the Mean Scores of the Experimental, Control, and Placebo Groups

\begin{tabular}{lllccccc}
\hline \multirow{2}{*}{ Post Hoc } & Groups & Groups & Mean Difference & Std. Error & p & & \multicolumn{2}{c}{$\begin{array}{c}\text { 95\% Confidence } \\
\text { Interval }\end{array}$} \\
\cline { 3 - 8 } Scheffe & Experimental & Control & 13.69 & 4.81 & $.022^{*}$ & 1.64 & 25.74 \\
& Experimental & Placebo & 11.00 & 4.91 & .089 & -1.31 & 23.30 \\
& Control & Placebo & -2.69 & 4.81 & .86 & -14.74 & 9.36 \\
\hline
\end{tabular}

Table 5 shows that there was a significant difference between scores of the experimental group and control group $(p<.025)$. No significant difference was found between the other groups. When the mean scores of the groups were examined, the mean score of the experimental group was 12.82 and that of the control group was .88. This means that if the score increases, the tendency to lie decreases relatively. Although there was no significant difference between the scores of the experimental and placebo groups, the mean score of the experimental group decreased compared to the placebo group $[=12.82$ (experimental), $=1.82$ (placebo)]. These results show that positive psychology-based group counseling activities were successful in reducing the tendency to lie.

Hypothesis 3: "There is no significant difference between the pre-test and post-test lying tendency scores of the control and placebo groups." The Wilcoxon signed-rank test was used to test the third hypothesis of the study and the results are shown in Table 6.

Table 6.

Pre-Test and Post-Test Results of the Wilcoxon Signed-Rank Test and Lying Scale of the Control and Placebo Groups

\begin{tabular}{|c|c|c|c|c|c|c|}
\hline & & $\mathbf{n}$ & Mean rank & Mean Sum & $\mathbf{z}$ & p \\
\hline \multirow{4}{*}{$\begin{array}{l}\text { Control Group } \\
\text { Pre-test - Post-test }\end{array}$} & Negative Rank & 11 & 13 & 143 & \multirow{4}{*}{-.200} & \multirow{4}{*}{.841} \\
\hline & Positive Rank & 13 & 12.08 & 157 & & \\
\hline & Equal & 0 & & & & \\
\hline & Total & 24 & & & & \\
\hline \multirow{4}{*}{$\begin{array}{l}\text { Control Group } \\
\text { Lying for social reasons } \\
\text { Pre-test - Post-test }\end{array}$} & Negative Rank & 10 & 11.35 & 113.5 & \multirow{4}{*}{-.070} & \multirow{4}{*}{.945} \\
\hline & Positive Rank & 11 & 10.68 & 117.5 & & \\
\hline & Equal & 3 & & & & \\
\hline & Total & 24 & & & & \\
\hline \multirow{4}{*}{$\begin{array}{l}\text { Control Group } \\
\text { Lying for emotional reasons } \\
\text { Pre-test - Post-test }\end{array}$} & Negative Rank & 11 & 12.32 & 135.5 & \multirow{4}{*}{-.415} & \multirow{4}{*}{.678} \\
\hline & Positive Rank & 13 & 12.65 & 164.5 & & \\
\hline & Equal & 0 & & & & \\
\hline & Total & 24 & & & & \\
\hline \multirow{4}{*}{$\begin{array}{l}\text { Placebo Group } \\
\text { Pre-test - Post-test }\end{array}$} & Negative Rank & 10 & 11.05 & 110.50 & \multirow{4}{*}{-.624} & \multirow{4}{*}{.532} \\
\hline & Positive Rank & 9 & 8.83 & 79.50 & & \\
\hline & Equal & 3 & & & & \\
\hline & Total & 22 & & & & \\
\hline \multirow{4}{*}{$\begin{array}{l}\text { Placebo Group } \\
\text { Lying for social reasons } \\
\text { Pre-test - Post-test }\end{array}$} & Negative Rank & 11 & 10.05 & 110.5 & \multirow{4}{*}{-.625} & \multirow{4}{*}{.532} \\
\hline & Positive Rank & 8 & 9.94 & 79.5 & & \\
\hline & Equal & 3 & & & & \\
\hline & Total & 22 & & & & \\
\hline \multirow{4}{*}{$\begin{array}{l}\text { Placebo Group } \\
\text { Lying for emotional reasons } \\
\text { Pre-test - Post-test }\end{array}$} & Negative Rank & 10 & 8.85 & 88.5 & \multirow{4}{*}{-.569} & \multirow{4}{*}{.569} \\
\hline & Positive Rank & 7 & 9.21 & 64.5 & & \\
\hline & Equal & 5 & & & & \\
\hline & Total & 22 & & & & \\
\hline
\end{tabular}


As Table 6 shows, no significant difference was found between the scores (total score and subscale scores) on the scale of lying tendency from the control and placebo groups.

Hypothesis 4: "There is a difference between the pre-test and post-test scores of the placebo group in the assertiveness inventory." To test the fourth hypothesis of the study, the Wilcoxon signed-rank test was used and the results are shown in Table 7.

Table 7 .

Pre-test and Post-test Assertiveness Inventory and the Wilcoxon Signed-Rank Test Results of the Placebo Group

\begin{tabular}{|c|c|c|c|c|c|c|c|c|c|}
\hline & & $\overline{\mathbf{x}}$ & sd & & $\mathbf{n}$ & Mean rank & Mean Sum & $\mathbf{z}$ & p \\
\hline \multirow{4}{*}{ 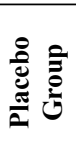 } & \multirow{2}{*}{ Pre-test } & \multirow{2}{*}{29.73} & \multirow{2}{*}{7.09} & Negative Rank & 5 & 7.90 & 39.5 & \multirow{4}{*}{-2.01} & \multirow{4}{*}{.045} \\
\hline & & & & Positive Rank & 13 & 10.12 & 131.5 & & \\
\hline & \multirow{2}{*}{ Post-test } & \multirow{2}{*}{32.18} & \multirow{2}{*}{6.02} & Equal & 4 & & & & \\
\hline & & & & Total & 22 & & & & \\
\hline
\end{tabular}

Table 7 shows an increase in the assertiveness inventory scores of the students in the placebo group before and after the procedure $(\mathrm{p}<.05)[=29.73$ (pre-test $)=32.18$ (posttest)]. According to these results, the training program to develop assertiveness skills was effective in the placebo group.

\section{Quantitative Results}

To determine the effectiveness of positive psychology-based group counseling activities in detail, opinions of the teachers who taught students in the experimental group were obtained and the results were processed in line with the determined themes and presented in Table 8.

Table 8 .

Results of Qualitative Interviews (Teacher)

T2: Indeed, when people accept themselves as they are, they feel happier, more confident, and more successful.

T5: The student S6 can object without crossing the line. This indicates both courage and self-confidence. I think it is beneficial for children to participate in these activities.I think it contributes to self-confidence positively.

T1: For example, the student S5 has self-confidence. That student has an individualized training program (ITP) and said the other day: "Teacher, you will do a separate exam for me." This shows his/her self-acceptance.

T2: I have noticed different behaviors of S5. For example, he/she normally does not listen to the lesson. That student, also receiving an ITP, came to me the other day and said:"Could you do a separate written exam for me?". This is actually an example of accepting oneself as she/he is.

T1: There are two girls sitting in the front desks, for example. They did not talk before, but then they became confident.

T3: The student S4 was trying to resemble the student S1. S4 could not be himself/herself and was trying to increase his/her social acceptance in this way. This has decreased. The state of self-acceptance increased.

T4: S13 started to react less and S14 started to speak less. S3 started to raise their hand more often. When I assigned a task, he/she started to make an effort to complete it. 
Table 8.

Results of Qualitative Interviews (Teacher)

\section{STATEMENT}

THEME

T3: Students requested a rearrangement in the seating plan in the classroom. I thought that this change would not be fair because it would affect others. I explained this to the children. Students said it would be unfair for others if thought of in terms of justice. And then, they did not make such a request anymore. Now I think it means that the concept of social justice for the children has improved.

T3: They bravely told me about an event they had with a teacher. They frankly showed that they did not want to hurt the teacher. This, actually, shows that they have gained courage. Later, they solved this problem with their teacher without even causing a problem. This shows that students' courage and kindness have developed.

T4: I have observed bantering behaviors among them. They could make jokes without going beyond the limit. Even to me. This shows their courage.

T1: S10 made progress in fulfilling his/her responsibilities. In fact, I think the responsibility behavior of the class has increased en masse. Even S11, who was not involved in any activities before, did it alone the other day. I have noticed that whenever there is task to be done in the classroom, they do it on their own. Without anyone saying anything.

T2: One day the key for the classroom locker was lost. I was asking who took it last. S9 stood up courageously and said he/she had taken it but did not know where it was now. This drew my attention. That student has changed a lot in terms of kindness. He/She was more peevish before. Now, he/she is more well-adjusted.

T4: I have seen examples of forgiving a friend. They can show forgiveness after problems.

T5: You see they have experienced serious problems. But they love each other. You see they have forgiven themselves. I think more examples about this can be given.

T3: Self-confidence increases as new solutions increase. I see examples of this. I was talking with a student after this process. "Teacher, I have learned to thank people now, " he/she said. "I used to solve my problems by fighting, now I express myself and thank others when something good happens".

T3: Kindness has increased. They are more patient now.

T2: I remember there are kind students. Students thank each other now.

T2: There is an aquarium in the classroom, and students feed the fish knowing their responsibilities and without hurting each other. For example, S9 was in charge of cleaning the aquarium. While this student normally did not fulfill his responsibilities in his classes, he/ she started to do this job completely. I used to see that students even insulted each other when we assigned a task to a student. Now, I like seeing them do something by embracing the responsibility and without hurting each other.

T4: S14 left for another school at the end of the term; the class became sad about that.

T3: Children used to solve the problems among themselves by quarreling. I am a class teacher. I am dealing with less problems now. Tolerance has increased.

T4: An absolutely positive atmosphere has been created in the classroom. To me and to themselves. For example, take S12. No matter how much I tried to engage him/her in a dialogue, I could not reduce the problems. But after this process, I can say that he/she calmed down and became more respectful, became quite calm.

T5: I have noticed positive changes in terms of patience and respect.

To determine the effectiveness of positive psychology-based group counseling activities in detail, parents of the students in the experimental group were interviewed and the results were processed in line with the determined themes and presented in Table 9. 
Table 9.

Results of Qualitative Interviews (Parent)

\section{STATEMENT}

THEME

P1: My child is aware of his/her responsibility. He knows his/her feelings. I have noticed that he/she displays behaviors that he/she should at home better after your practices in the classroom.

P1: He/She became more mature and understanding at the end of the term compared to the beginning of the term.

P2: I have seen that, after this study, he/she expressed himself/herself better. He/She was more withdrawn before. Now it is better.

P2: He/She had a row with his/her friends at the social facility and bravely explained what he/ she did, including his/her own mistakes. He/She expressed the situations in which he/she regretted doing wrong. This was very important.

P2: He/She became smarter. He/She became more patient. Sometimes he/she produces immediate reactions, but these are consequences of the life-stage he/she is in. He/She has more self-confidence now.

P2: We went through an incident in the weeks when you talked about justice. Our financial situation is not very good. One day he asked me for money to buy something he wanted. I gave some. He brought back some of the money I had given in the evening. I said, "What is this son?" He said: "I used the amount needed. This is the rest; you can buy something for my siblings." Normally he would not do that.

P1: I have observed him/her after the processes; sometimes he/she is very courageous and becomes controlled.

P2: If there was a problem between me and my partner, for example, or if we had a row, my daughter would say right and wrong. She is very careful to say these things without hurting us. She distinguishes right from wrong.

P2: He/She had a row with his/her friends at the social facility and bravely explained what he/ she did, including his/her own mistakes. He/She expressed the situations in which he/she regretted doing wrong. This was very important.

P1: I am a housewife; sometimes he/she does not help and doesn't care. I get angry inevitably. Then he/she can come and make an effort to atone. He/She tells me what you have said in the class. He/She has said "One day you said God is forgiving, why should we not forgive?"

P1: They quarreled with their friends the other day and then forgave each other. He/She supported his/her friend in that event. He/She learned to take a step back when needed.

P3: Sometimes I make mistakes, too; he/she says "I can't believe you mom. How can you do this." He/She does not say these things angrily or hurtfully.

P3: For example, I simply do not get on with his/her aunt. I do not call her. If we were to talk about this, he/she said: "Let it be mom, you are older, be understanding, she is our aunt after all. You call her." He/She is much more tolerant than before.

$\mathrm{P} 1$ : He/She is different now compared to the last period. Regarding gratitude, he/she is expressing all kinds of his/her love and establishes closer relationships. While talking with someone he/she loves, he/she talks clearly and carefully not to offend.

$\mathrm{P} 2$ : He/She is a child who knows how to speak, who thanks, who can express his/her feelings and thoughts. In fact, this started to draw my attention more.

P3: For example, if he/she wanted something, he/she would persist. If I say "No", he understands. He/She is not persistent anymore.

P2: He/She became smarter. He/She became more patient. Sometimes he/she produces immediate reactions, but these are consequences of the life-stage he/she is in. He/She has more self-confidence now.

\section{Discussion and Conclusion}

This study was carried out to test the effect of the program, which was prepared on the basis of positive psychology theory and implemented as 15-week group counseling activities, on 7th grade students' lying tendencies. In line with this 
purpose, the hypotheses were tested by analyzing the students' scores obtained from the lying tendency scale and the results obtained from the qualitative data about the program applied to the experimental group were included.

The first hypothesis of the study was "There is a significant difference between the pre-test and post-test scores of the experimental group." According to the results, positive psychology-based group counseling activities were effective and reduced the experimental group's tendency to lie. Accordingly, the hypothesis was confirmed.

When the gains of the program were examined, the self-acceptance behavior used the virtues of justice, courage, forgiveness, gratitude, and patience to reduce the tendency to lie. When the qualitative interviews conducted were evaluated within this scope, remarkable opinions about self-confidence status, in other words, changes in self-acceptance, were noted. Another study found that the locus of control is a determinant of subjective well-being and is significantly related to self-acceptance (Malhotra, 2017). From this perspective, self-acceptance is related to self-control.

When the interview records were examined, the virtue of justice was reflected in both classroom experiences and family relationships. Tongeren, Welch, Davis, Green, \& Worthington (2012) noted that justice is related to forgiveness. Another study found a significant relationship between forgiveness and psychological well-being (Singh \& Sharma, 2018). However, Chen, Harris, Worthington, \& VanderWeele (2018) reported that forgiveness is positively associated with all psychosocial well-being outcomes. Accordingly, positive psychology-based group guidance activities helped students internalize virtues of justice and forgiveness and turn these virtues into behaviors. An individual who has the virtues of forgiveness and justice cannot act unfairly and cannot engage in lying behavior by showing forgiveness in unfair situations.

A study found that acts of courage occur with more confidence, less fear, and less personal limitations (Pury, Kowalski, \& Spearman, 2007). Based on the interview records, there were remarkable statements about the reflection of the virtue of courage on life. The fact that a person becomes courageous and takes responsibility in the face of any mistake he/she has made is related to the characteristic of courage. In this context, a person who has the characteristics of courage cannot exhibit the behavior of lying.

Nezlek, Newman, \& Thrash (2017) reported that feelings of gratitude increase well-being. In addition, Cheetham, Williams, \& Bednall (2016) reported that pride, satisfaction, compassion, and gratitude, which they regarded as positive emotions, contributed to well-being: while pride and compassion contributed indirectly, satisfaction and gratitude contributed directly. Biçer and Sarıçam (2015) observed statistical differences between the levels of self-transcendence and spiritual well-being according to age. Southwell and Gould (2017) carried out a study with an experimental and control 
group and used three-week gratitude activities. They reported a decrease in depression, anxiety, stress, and perceived sleep difficulties scores of the experimental group, while the scores of the control group were not significantly different. According to Bono et al. (2019), gratitude development reduces antisocial behavior over time. Aghababaei and Tabik (2013) examined the relationship of religious gratitude and dispositional gratitude with mental health, subjective well-being, and personality. Studies have reported that gratitude has a moderate to strong negative correlation with mental illness and a positive correlation with subjective well-being. According to the interviews, kindness and patience characteristics became embedded in the students' behaviors. Emotional control in interpersonal relationships undoubtedly emerges when the virtue of patience is reflected in behaviors. We saw in the interviews that the virtue of patience was reflected in behaviors. Doğan (2017) examined the relationships between patience and psychological well-being and found positive significant correlations between the two. Bach and Guse (2015) focused on developing compassion with their patience and meditation training and investigated its effect on adolescents' psychological well-being. The study found that adolescents who received the training had statistically significant increases in personal development compared to those who did not. The quantitative results, interview records, and literature review show that positive psychology-based group counseling activities help the emergence of self-acceptance behavior and increase the virtues of justice, courage, forgiveness, gratitude, and patience. As a result, students' tendency to lie decreased.

The second hypothesis of the study was "There is a significant difference between the mean pre-test and post-test scores of all the groups in favor of the experimental group". As a result of the method used to analyze whether the mean scores in two or more related sets of measurements differ significantly from each other (Büyüköztürk, 2003), mean scores of the experimental and control groups significantly differed. This is important. When all the results were evaluated together, positive psychologybased group counseling activities developed and applied within the scope of the study reduced students' tendency to lie.

The third hypothesis of the study was "There is no significant difference between the pre-test and post-test lying tendency scores of the control and placebo groups in favor of experimental group". No significant difference was found ( $p>.05)$ in both total test scores and the scores obtained from the subscales of the lying tendency scale. Thus, the hypothesis was confirmed. No intervention regarding lying tendency was applied to the control and placebo groups in the study. Accordingly, no change in lying tendencies of the groups were expected. This was supported by the results of the analyses; in other words, the purpose of forming the groups attained its aim. The significant difference in the first hypothesis (experimental group) of the study and the lack of a significant difference in the third hypothesis (control and placebo groups) show that positive psychology-based group counseling activities achieved their purpose. 
The fourth hypothesis of the study was "There is a difference between the pre-test and post-test scores of the placebo group in the assertiveness inventory." According to the results, a significant difference was found between the pre-test and post-test scores of the placebo group in the assertiveness inventory. These results comply with those of the study by Ugürol (2010) and indicate that the hypothesis was confirmed.

In conclusion, positive psychology-based group counseling activities reduced the tendency to lie. The program prepared in this context can be used in middle schools. The students included in the study shared their moods during the activities and made efforts to prepare the products that the study required. In this context, it may be useful to increase the application time to reveal the feelings and thoughts of the students in depth and to diversify the products they produce. This will help the program goals to be achieved completely.

\section{References}

Aghababaei, N., Tabik, M. T. (2013). Gratitude and mental health: differences between religious and general gratitude in a Muslim context. Mental Health, Religion \& Culture, 16(8), 761-766. https://doi.org/10.1080/13674676.2012.718754

Akın, A., Yalnız, A. (2015). Yaşam memnuniyeti ölçeği Türkçe formu: Geçerlik ve güvenirlik çalışması. Elektronik Sosyal Bilimler Dergisi, 14(54), 95-102. http://dergipark.gov.tr/ harranilahiyatdergisi/issue/26239/276347

Akyüz, H., Yaşartürk, F., Aydın, İ., Zorba, E., Türkmen, M. (2017). Üniversite öğrencilerinin yaşam kalitesi ve mutluluk düzeyleri arasındaki ilişkinin incelenmesi. International Journal of Cultural and Social Studies, 3, 253-262. https://dergipark.org.tr/tr/download/article-file/388849

Amerikan Psikiyatri Birliği. (2000). DSM-IV-TR (Çev. E. Köroğlu). Ankara: Hyb Yayınları.

Aspinwall L. G., Staudinger, U. M. (ed). (2003). A psychology of human strengths. Washington, DC, US: American Psychological Association.

Avşaroğlu, S., Üre, Ö. (2007). Üniversite öğrencilerinin karar vermede özsayg1, karar verme ve stresle başa çıkma stillerinin benlik saygısı ve bazı değişkenler açısından incelenmesi. Selçuk Üniversitesi Sosyal Bilimler Enstitüsü Dergisi, 18, 85-100. http://dergisosyalbil.selcuk.edu.tr/ susbed/article/view/439/421

Bach, J. M., Guse, T. (2015). The effect of contemplation and meditation on 'great compassion' on the psychological well-being of adolescents. The Journal of Positive Psychology, 10(4), 359369. https://doi.org/10.1080/17439760.2014.965268

Barker, D. G., Gałajda, D. (ed). (2016). Positive psychology perspectives on foreign language learning and teaching. Poland: Springer.

Biçer, B., Sarıçam, H. (2015). Öz-aşkınlık ile manevi iyi olma arasındaki ilişki. Felsefe Eğitim ve Bilim Tarihi Sempozyumu.

Bono, G., Froh, J. J., Disabato, D.., Blalock, D., McKnight, P., Bausert, S. (2019). Gratitude's role in adolescent antisocial and prosocial behavior: A 4-year longitudinal investigation. The Journal of Positive Psychology, 14(2), 230-243. http://10.1080/17439760.2017.1402078

Butcher, J. N., Mineka, S., Hooley, J. M. (2013). Anormal psikoloji (Çev. O. Gündüz). İstanbul: Kaknüs Yayınları. 
Büyüköztürk, Ş. (2003). Sosyal bilimler için veri analizi el kitabı (3. Baskı). Ankara: Pegem A Yayıncılık. Büyüköztürk, Ş. (2011). Deneysel desenler (3. Bask1). Ankara: Pegem Akademi Yayınc1lık.

Büyüköztürk, Ş., Çakmak, E. K., Akgün, Ö. E., Karadeniz, Ş., Demirel, F. (2014). Bilimsel araştırma yöntemleri (18. Baskı). Ankara: Pegem Akademi Yayıncılık.

Cheetham, E. B., Williams, L. A., Bednall, T. C. (2016). A differentiated approach to the link between positive emotion, motivation, and eudemonic well-being. The Journal of Positive Psychology, 11(6). http://10.1080/17439760.2016.1152502

Chen, Y., Harris, S. K., Worthington Jr, E. L., VanderWeele, T. J., (2019). Religiously or spirituallymotivated forgiveness and subsequent health and well-being among young adults: An outcome-wide analysis. The Journal of Positive Psychology, 14(5). https://doi.org/10.1080/17439760.2018.1519591

Chu, R., Chao, L. (2015). Counseling psychology. India: John Wiley \& Sons, Ltd.

Cohen, J. (1988). Statistical power analysis fort he behavioral science (Second Edition). New York: Lawrance Erlbaum Associates.

Compton, W. C., Hoffman, E. (2013). Positive psychology: The science of happiness and flourishing, (Second edition). Belmont: Wadsworth, Cengage Learning.

Creswell, J. W. (2016). Araştırma Deseni (2. Baskı). Ankara: Eğiten Kitap.

Creswell, J. W., Clark, V. L. P. (2014). Karma yöntem araştırmaları tasarımı ve yürütülmesi. İstanbul: Anı Yayıncılık.

Csikszentmihalyi, M., (1997). Finding flow. New York: Basic Books.

Csikszentmihalyi, M., (2007). Creativity. New York: HarperCollins Publishers Inc.

Csikszentmihalyi, M. (2014). Flow and the foundations of positive psychology. New York: Springer

Doğan, M. (2017). Karakter gücü olarak sabır ve psikolojik iyi oluş ilişkisi. The Journal of Happiness \& Well-Being, 5(1), 134-153. https://www.journalofhappiness.net/frontend//articles/ pdf/v5i1/sabir-2pdf.pdf

Driver, M. (2011). Coaching positively. New York: Open University Press.

Druzin B. H., J. Li, (2017). Yalan söyleme eyleminin suç olarak öngörülmesi: eğer mümkün ise hangi şartlar altında yalan söylemek suç olarak öngörülebilir? (Çev. N. Kırkbeşoğlu) Küresel Bakış Dergisi, 8(23), 1-50.

Edmonds, W. A., Kennedy, T. D. (2017). An Applied Guide to Research Designs Quantitative, Qualitative, and Mixed Methods. California: Sage Pub.

Ekman, P. (1992). Telling lies. New York: W. W. Norton Company.

Erdal, T. (2016). Dede korkut kitabında yalan ve aldatma kavramlar1. Milli Folklor, 28, 83-106. http://www.millifolklor.com/PdfViewer.aspx?Sayi=109\&Sayfa=80

Erdoğan, Ö., Uçukoğlu, H. (2011). İlköğretim okulu öğrencilerinin anne baba tutumu algıları ile atılganlık ve olumsuz değerlendirilmekten korkma düzeyleri arasındaki ilişkiler. Kastamonu Ĕ̈itim Dergisi, 19(1), 51-72. https://dergipark.org.tr/tr/pub/kefdergi/issue/49053/625821

Ford, C. V. (1997). Yalan! Yalan!! Yalan!!! (Çev. Ş. Küçükal). Ankara: HYB Yayıncılık.

Girişken, N. (1974). Çocuk eğitiminde ailenin etkisi. Atatürk Üniversitesi Ziraat Fakültesi Dergisi, 5(2-3), 141-160. https://dergipark.org.tr/tr/pub/ataunizfd/issue/2969/41132

Goleman, D. (1999). Hayati yalanlar basit gerçekler (Çev. B. Yanık). İstanbul: Arion Yayınevi.

Gündoğar, D., Demirci, S. (2007). Konfabulasyon (Masallama): İlgi çeken ancak yeterince bilinmeyen bir belirti. Türk Psikiyatri Dergisi, 18(2), 172-178. http://www.turkpsikiyatri.com/ C18S2/konfabulasyon.pdf 
Kabakçı, Ö. F. (2013). Karakter güçleri açısından pozitif gençlik gelişiminin incelenmesi.

(Doktora tezi, Hacettepe Üniversitesi, Sosyal Bilimler Enstitüsü, İzmir). https://tez.yok.gov.tr/ UlusalTezMerkezi/ adresinden ulaşılmıştır.

Kangal, A. (2013). Mutluluk üzerine kavramsal bir değerlendirme ve Türk hane halkı için bazı sonuçlar. Elektronik Sosyal Bilimler Dergisi, 12(44), 214-233. https://dergipark.org.tr/tr/pub/ esosder/issue/6158/82771

Kanlıkılıçer, P. (2005). Okul öncesi davranış, sorunları tarama ölçeği: Geçerlilik ve güvenilirlik çalışması. (Yüksek lisans tezi, Marmara Üniversitesi, Eğitim Bilimleri Enstitüsü, İstanbul). https://tez.yok.gov.tr/UlusalTezMerkezi/ adresinden ulaşılmıştır.

Karpman, B. (1949). Lying: A minor inquiry into the ethics of neurotic and psychopathic behavior. Journal of Criminal Law and Criminology, 40(2), 135-157. http://dx.doi.org/10.1007/BF01561309

Koç, B. (2007). Çatışma bağlamında yalan ve din ilişkisi. Dini Araştırmalar, 10(30), 215-242. https://dergipark.org.tr/tr/pub/da/issue/4467/61617

Korkmaz, M., Germir, H. N., Yücel, A. S., Gürkan, A. (2015). Yaşam memnuniyeti üzerinde etkili olan sosyodemografik bileşenler üzerine bir analiz. Uluslararası Hakemli Psikiyatri ve Psikoloji Araştırmaları Dergisi, 3(2), 78-111.

Köroğlu, E., Bayraktar, S. (2010). Kişilik bozuklukları. Ankara: HYB Yayınları.

Linley, P. A., Joseph, S. (Ed). (2004). Positive psychology in practice. New Jersey: John Wiley \& Sons Inc.

Lopez, S. J. (ed). (2008). Positive psychology exploring the best in people. Usa: Praeger Publishers.

Lopez, S. J. (ed). (2009). The encyclopedia of positive psychology. Malden MA: Blackwell Publishing Ltd.

Malhotra, R. (2017). Locus of control and well-being among college students. Indian Journal of Positive Psychology, 8(2), 231-236

Marujo, H. A., Neto, L. M. N. (ed). (2014). Positive nations and communities. New York: Springer.

Maslow, A. H. (1954). Motivation and personality. Harper \& Row Publishers Inc.

Maslow, A. (2001). İnsan olmanın psikolojisi (Çev. O. Gündüz). İstanbul: Kuraldışı Yayıncılık.

Meyer, P. S., Johnson, D. P., Parks, A., Iwanski, C., Penn, D. L. (2012). Positive living: A pilot study of group positive psychotherapy for people with schizophrenia. The Journal of Positive Psychology, 7(3), 239-248. https://doi.org/10.1080/17439760.2012.677467

Nezlek, J. B., Newman. D. B., Thrash, T. M. (2017). A daily diary study of relationships between feelings of gratitude and well-being. The Journal of Positive Psychology,12(4), 323-332. http:// 10.1080/17439760.2016.1198923

Özer, B., Bozkurt, N., Tuncay, A. (2005). İstenmeyen öğrenci davranışları ve öğretmenlerin kullandıkları başa çıkma stratejileri. Turkish Journal of Education 1(2), 152-189. https:// dergipark.org.tr/tr/download/article-file/402886

Parks, A. C., Schueller, S. M. (ed). (2014). The Wiley Blackwell handbook of positive psychological interventions. John Wiley \& Sons, Ltd.

Patton, M. Q. (2015). Qualitative research \& evaluation methods : Integrating theory and practice. California: Sage Pub.

Peterson, C., Seligman, M. E. P. (2004). Character strengths and virtues a handbook and classification. New York: Oxford University Press.

Pury, C. L. S., Kowalski, R. M., Spearman, J. (2007). Distinctions between general and personal courage. The Journal of Positive Psychology, 2(2), 99-114. https://doi. org/10.1080/17439760701237962 
Ruini, C. (2017). Positive psychology in the clinical domains. Switzerland: Springer.

Samsakçı, M. (2015). Sanat-Edebiyatta yalanın yeri ve değeri üzerine. Yeni Türk Edebiyatı Araştırmalarl, 7(14), 91-109. http://www.ytearastirmalari.com/DergiTamDetay. aspx?ID=215\&Detay=Ozet

Seligman, M. E. P., Csikszentmihalyi, M. (2000). Positive psychology an introduction. American Psychologist, 55(1), 5-14. http://dx.doi.org/10.1037/0003-066X.55.1.5

Singh, H., Sharma, U. (2018). Effect of forgiveness on psychological well-being. Indian Journal of Positive Psychology, 9(2), 258-262.

Solano, A. C. (ed). (2014). Positive psychology in Latin America. New York: Springer.

Southwell, S., Gould, E. (2017). A randomized wait list-controlled pre-post-follow-up trial of a gratitude diary with a distressed sample. The Journal of Positive Psychology, 12(6). 579-593. ht tp://10.1080/17439760.2016.1221127

Soysald1, M.(2005). Kalbin manevîhastalıklarından yalan vekorunmayolları. Tasavvuf: Ilmîve Akademik Araştırma Dergisi,6(15), 89-105. http://www.tasavvufdergisi.net/Makaleler/1232932170_15.5.pdf

Şehirli, N. (2007). Çocuk davranışlarını değerlendirme ölçeği'nin geliştirilmesi ve bazı değişkenlere göre incelenmesi. (Yüksek lisans tezi, Gazi Üniversitesi, Eğitim Bilimleri Enstitüsü, Ankara). https://tez.yok.gov.tr/UlusalTezMerkezi/ adresinden ulaşılmıştır.

Tongeren, D. R. V., Welch,R. D., Davis, D. E., Green, J. D., Worthington Jr, E. L. (2012). Priming virtue: Forgiveness and justice elicit divergent moral judgments among religious individuals. The Journal of Positive Psychology, 7(5), 405-415. https://doi.org/10.1080/17439760.2012.707228

Tura, S. M. (2005). Günümüzde psikoterapi. İstanbul: Metis Yayınları.

Yaman, E., Mermer, E. Ç., Mutlugil, S. (2009). İlköğretim okulu öğrencilerinin etik davranışlara ilişkin görüşleri: Nitel bir araştırma. Değerler Eğitimi Dergisi, 7(17), 93-108. https://ded.dem. org.tr/gorsel/pdf/ded-17-makale-5.pdf

Yıldırım, A., Şimşek, H. (1999). Sosyal bilimlerde nitel araştırma yöntemleri (9. Baskı). Ankara: Seçkin Yayıncılık.

Ugürol, Y. (2010). Atılganlık becerilerini geliştirme eğitimi programının ilköğretim 7. sınıf ögrencilerinin zorbalığa uğrama düzeylerinin azaltılmasına etkisi: Yibo örneği. (Doktora tezi, Karadeniz Teknik Üniversitesi, Sosyal Bilimler Enstitüsü, Trabzon). https://tez.yok.gov.tr/ UlusalTezMerkezi/ adresinden ulaşılmıştır.

Ulusoy, M. A. (2020). Pozitif psikoloji temelli grup rehberliğinin 7. sınıf öğrencilerinin yalan söyleme eğilimlerine ve benlik saygılarına etkisi. (Doktora tezi, Marmara Üniversitesi, Eğitim Bilimleri Enstitüsü, İstanbul). https://tez.yok.gov.tr/UlusalTezMerkezi/ adresinden ulaşılmıştır.

Uzun, S. (2011). Ergenlerde yalan tutumuna psiko-sosyal yaklaşım (Sakarya Örneği).(Yüksek lisans tezi, Sakarya Üniversitesi, Sosyal Bilimler Enstitüsü, Sakarya). https://tez.yok.gov.tr/ UlusalTezMerkezi/ adresinden ulaşılmıştır.

Ünal, H. (2006). Davranım bozukluğu tanısı alan ilköğretim öğrencilerine okullarda sunulan danışmanlık hizmetlerinin incelenmesi. (Yüksek lisans tezi, Çukurova Üniversitesi, Sosyal Bilimler Enstitüsü, Adana). https://tez.yok.gov.tr/UlusalTezMerkezi/ adresinden ulaşılmıştır. 